\title{
APRESENTAÇÃO
}

\section{ARTE NA EDUCAÇÃO: PESQUISAS E EXPERIÊNCIAS EM DIÁLOGO}

$\mathscr{P}$

esquisando as temáticas já contempladas nos números dos $\mathrm{Ca}$ dernos CEDES desde 1980, constatamos a ausência de temas relacionados à arte, à educação estética ou à educação e arte. Se, por um lado, há um crescente número de estudos, pesquisas e produções na área, ainda é relativamente pequeno o número de publicaçōes divulgando, socializando e permitindo a ampliação do debate.

Se a arte-educação articulou-se, historicamente, através de discussões e propostas que envolviam apenas as artes visuais, compreendemos hoje a necessidade de integrar no campo a dança, a música, o teatro, o cinema e a literatura. Com o objetivo de dar visibilidade à multiplicidade de perspectivas que podem ser articuladas no território que circunda a arte na educação, organizamos o caderno temático "Arte na educação: pesquisas e experiências em diálogo", reunindo pesquisadores de diferentes instituições, nacionais e internacionais.

Trazemos para o debate a presença da arte em diferentes níveis de ensino, da educação básica ao ensino universitário; os fazeres no cotidiano educativo, envolvendo diferentes linguagens artísticas, na prática compartilhada com as crianças; a formação estética do professor como dinâmica essencial para poder estar com os estudantes, perceber, ouvir, ver suas múltiplas expressóes, no processo de criação e apropriação do mundo. A proposta de diálogo entre educação e arte também abarca a necessária reflexão sobre a função da arte no mundo contemporâneo.

O primeiro artigo, "A educação através da arte para um futuro sustentável”, afirma que a arte e, particularmente, a arte na educação têm um papel importante na construção de um futuro sustentável, 
pois é um campo do conhecimento que possibilita o cultivo da criatividade, inovação e pensamento crítico, capacidades fundamentais para uma cultura emancipadora de igualdade e responsabilidade social. "Arte e pedagogia: além dos territórios demarcados" propõe uma reflexão sobre a necessidade, apesar das dificuldades, de aproximação de profissionais dos campos da arte e da pedagogia. Tomando como referência a psicologia junguiana, destaca a importância de encontrar na imagem o fio condutor para a pesquisa em arte e a necessidade de desenvolvermos uma observação atenta e cuidadosa durante a pesquisa, dando tempo para emergir tudo o que for necessário ser descoberto. A pergunta que percorre o artigo "Para encantar é preciso encantar-se: danças circulares na formação de professores" é assim formulada: como contribuir com o processo de encantamento dos professores, como alimentar a sensibilidade, nos percursos da formação universitária? Buscando respostas no processo de pesquisa, a autora identifica na experiência com as danças circulares, tradição de diferentes povos, um profícuo caminho pelo qual aquele espaço de encantamento, de inteireza, de educação estética, igualmente, pode ser provocado.

"Em direção à autenticidade: encontro com a diferença" apresenta reflexões sobre um estudo de caso, na Nova Zelândia, em uma classe de alunos de sete a nove anos. Investiga a motivação e os resultados gerados por um trabalho em equipe, que usa arte como base de integração para um exame histórico, social e pessoal. Levanta questôes sobre como professores de uma cultura dominante, e seus jovens alunos, podem se abrir às referências indígenas presentes na cultura de seu país e criar, com elas, um autêntico vínculo pessoal. "Segredos do coração: a escola como espaço para o olhar sensível" trata da experiência da construção, na escola, de um espaço para o afeto, no qual, através da atividade artística, torna-se possível trabalhar perdas, cultivar segredos, sonhos e desejos, permitindo a construção de um olhar sensível para as histórias de cada um e para a memória coletiva. "O ensino de artes visuais na escola no contexto da inclusão" discute, pautado na produção de conhecimento brasileira recente, o ensino de arte para alunos com deficiência. Valoriza a construção de um trabalho de ateliê e de fruição a partir da divulgação de resultados de pesquisas que falam de contextos educacionais e culturais brasileiros.

Além dos artigos que percorrem os enfoques já explicitados, para a seção Caleidoscópio contamos com a apresentação de notas de pesquisa 
que oferecem dados de uma investigação em curso, desenvolvida com licenciandos em Artes Visuais e Pedagogia, sobre práticas teatrais e processos de rememoração. Destacam-se, na referida pesquisa, a discussão e análise sobre a relação entre elementos da linguagem teatral e os processos de rememoração e ressignificação de memórias. Dessa maneira, a investigação busca identificar possíveis contribuições da ação formativa na construção de reflexões e procedimentos norteadores das práticas educativas dos futuros educadores. Ao contemplar a linguagem das chamadas artes cênicas no processo de uma pesquisa constituída nas fronteiras entre educação e arte, as autoras problematizam a necessária integração entre as diferentes linguagens da arte como campo de conhecimento.

Ao propormos este caderno temático, reafirmamos a necessidade de redescobrir o lugar da arte na escola e fora dela, redimensionando a essencialidade da sua presença na vida humana. Acreditamos que esta é uma forma de contribuir para o debate e, ao mesmo tempo, apontar questões que possam subsidiar políticas públicas efetivas neste campo.

\author{
Ana Angélica Albano \\ LUCIANA ESMERALDA OsTETTO
}

(Organizadoras) 